\title{
Quality of life after treatment for cervical cancer
}

\author{
Qualidade de vida após o tratamento do câncer do colo do útero \\ Calidad de vida después del tratamiento del cáncer cervical
}

\begin{abstract}
Rafaella Araújo Correia ${ }^{1}$
Cristine Vieira do Bonfim ${ }^{1,2}$

Daniela Karina da Silva Ferreira ${ }^{1}(1)$

Betise Mery Alencar Sousa Macau Furtado ${ }^{3}$

Solange Laurentino dos Santos ${ }^{1}$ (iD)

1. Universidade Federal de Pernambuco.

Recife, PE, Brasil.

2. Fundação Joaquim Nabuco.

Recife, PE, Brasil.

3. Universidade de Pernambuco.

Recife, PE, Brasil.

4. Instituto de Medicina Integral Professor

Fernando Figueira. Recife, PE, Brasil.
\end{abstract}

Heitor Victor Veiga da Costa ${ }^{2}$ (iD)

Kéllida Moreira Alves Feitosa ${ }^{4}$ (1)
Corresponding author:

Cristine Vieira do Bonfim.

E-mail: cristine.bonfim@uol.com.br

Submitted on $04 / 28 / 2018$

Accepted on 09/06/2018.

DOI: 10.1590/2177-9465-EAN-2018-0130

\begin{abstract}
Objective: Identify the quality of life of women treated for cervical cancer according to their clinical and socioeconomic characteristics. Methods: This was a analytical study on women who were treated for cervical cancer by means of surgery, radiotherapy and chemotherapy. To evaluate their quality of life, the WHOQOL-bref questionnaire was applied. The Mann-Whitney test was used to investigate associations between domains and variables. Results: There were associations $(p<0.05)$ between the WHOQOL-bref domains and the variables of income, conjugal situation, leisure activities and treatment undergone. The physical and psychological domains were associated with overall quality of life $(R=0.54$ and $R=0.63$, respectively). Conclusions: Socioeconomic conditions and the type of treatment undergone influenced the quality of life of these women after their treatment. There is a need to increase the reach of cervical cancer screening among women who are less economically favored; and, after treatment, to offer alternative measures that soften the secondary effects.
\end{abstract}

Keywords: Uterine cervical neoplasms; Quality of life; Oncologic Nursing; Women's health.

\section{Resumo}

Objetivo: Identificar a qualidade de vida de mulheres após o tratamento de câncer do colo uterino, de acordo com suas características clínicas e socioeconômicas. Métodos: Trata-se de um estudo analítico com mulheres com câncer que foram tratadas com cirurgia, radioterapia e quimioterapia. Para avaliar a qualidade de vida, aplicou-se o questionário WHOQOL-bref. O teste de Mann-Whitney foi utilizado para investigar associações entre domínios e variáveis. Resultados: Houve associações $(p<0,05)$ entre os domínios do WHOQOL-bref e as variáveis renda, situação conjugal, atividades de lazer e tratamento realizado. Os domínios físico e psicológico foram associados à qualidade de vida global $(R=0,54$ e $R=0,63$, respectivamente) Conclusões: Condições socioeconômicas e o tipo de tratamento influenciaram a qualidade de vida dessas mulheres após o tratamento. É preciso aumentar o alcance do rastreio do câncer de colo do útero entre as mulheres que são menos favorecidas economicamente; e, após o tratamento, oferecer medidas alternativas que minimizam os efeitos secundários.

Palavras-chave: Neoplasias do colo uterino; Enfermagem Oncológica; Qualidade de vida; Saúde da mulher.

\section{Resumen}

Objetivo: Identificar la calidad de vida de las mujeres tratadas por cáncer de cuello uterino según sus características clínicas y socioeconómicas. Métodos: Este fue un estudio analítico sobre mujeres que fueron tratadas por cáncer de cuello uterino mediante cirugía, radioterapia y quimioterapia. Para evaluar su calidad de vida, se aplicó el cuestionario WHOQOL-bref. La prueba de MannWhitney se utilizó para investigar asociaciones entre dominios y variables. Resultados: Hubo asociaciones $(p<0.05)$ entre los dominios WHOQOL-bref y las variables de ingreso, situación conyugal, actividades de ocio y tratamiento. Los dominios físicos y psicológicos se asociaron con la calidad de vida general $(R=0.54$ y $R=0.63$, respectivamente). Conclusiones: Las condiciones socioeconómicas y el tipo de tratamiento sufrido influyeron en la calidad de vida de estas mujeres después de su tratamiento. Es necesario aumentar el alcance de las pruebas de detección del cáncer cervicouterino entre las mujeres económicamente menos favorecidas; $y$, después del tratamiento, ofrecer medidas alternativas que suavicen los efectos secundarios.

Palabras clave: Neoplasias del cuello uterino; Calidad de vida; Enfermería Oncológica; Salud de la mujer. 


\section{INTRODUCTION}

Cervical cancer is a public health concern around the world. ${ }^{1}$ The latest estimates indicate that cervical cancer is the fourth most diagnosed type of neoplasia among women and the fourth largest cause of death among women. Underdeveloped countries present the highest death rates (17.5 deaths for every 100,000 women) and prevalence (29.9 cases for every 100,000 women) of cervical cancer. ${ }^{1}$

In Brazil, the prevalence of this neoplasia was 19 cases for every 100,000 women and mortality was 7 deaths for every 100,000 women in 2012. ${ }^{1}$ More than 16,000 new cases of cervical cancer are expected for the year 2018. Among the regions of Brazil, the northeast and southeast regions will have a higher incidence $\left(6,030\right.$ and 4,420 , respectively). ${ }^{2}$

The main risk factor for developing cervical cancer is infection by the human papiloma virus (HPV). Persistent infection by HPV is considered a necessary cause, although insufficient to develop cervical cancer, which suggests that other factors are also involved in the carcinogenesis process. ${ }^{3}$ The formation of precursor lesions of cancer and cancer itself are due to multiple factors, such as age, multiparity, smoking, prolonged use of contraceptives, risky sexual behavior and coinfection with other sexually transmitted diseases. ${ }^{4}$ Precursor lesions that remain untreated can evolve over the long term to cervical cancer. ${ }^{3}$

For cervical cancer, the types of therapy available comprise surgery and radiotherapy for cases diagnosed early, or radiotherapy/chemotherapy for more advanced cases. ${ }^{5}$ However, the secundary effects and morbidity caused by these therapies deeply affect quality of life for these women.

The modalities of treatment cause sequels to the pelvic floor, thus leading to a series of dysfunctions relating mainly to the urinary and genital systems, along with interference with sex life. ${ }^{6,7}$ Furthermore, the disease has a psychosocial impact. Both the physical damage and the psychosocial impact lead to deterioration of quality of life. ${ }^{8}$

Increased survival and the possibility of cure or chronicity have led to greater interest in evaluating the quality of life of people with cancer, with the aim of achieving treatment based on comprehensive and humanized care. ${ }^{9,10}$ Quality of life is generally defined as "the individual's perception of his position in life in the context of culture and value system in which he lives and in relation to his goals, expectations, standards and concerns". ${ }^{11}$ The concept of quality of life as an outcome measurement within healthcare emerged as part of the scenario of prolongation of life expectancy through the progress of medicine during the twentieth century. ${ }^{12}$ Measurement of the way in which and the quality with which people were living these extra years became necessary. ${ }^{12}$

The effects secondary to cervical cancer treatment and to the disease itself have considerable impacts. It is therefore important to evaluate the quality of life of women treated for cervical cancer as an outcome, in order to consider the repercussions of the disease and its treatment.
Hence, with the aim of gathering knowledge to guide the planning of actions to meet the real necessities of these women after treatment, the objective of this study was to identify the quality of life of women who underwent cervical cancer treatment, according to their socioeconomic and clinical characteristics.

\section{METHODS}

This was an analytical study conducted at the Hospital, reference for cancer treatment that has been enabled as a unit for high-complexity cases within oncology (UNACON), also with a hematology service. ${ }^{13}$ This institution belongs to the public healthcare system (SUS) and provides therapy for approximately 60 patients per year who have been diagnosed with cervical cancer.

The population of this study consisted of women who underwent surgery, chemotherapy or radiotherapy as treatment for cervical cancer between January 2015 and December 2016. Participants were addressed while waiting for consultation (in gynecology or in hospital oncology) and those was proposed to participate in the research. those who agreed to participate and aged $\geq 18$ years whose treatment had ended at least three months previously were included in the study. The following were excluded: those with performance status (ECOG; Eastern Cooperative Oncology Group) >2, who, by definition, are patients with compromised quality of life; those with previous/current histories of other cancers or morbidities with potential harm to quality of life; and those who were undergoing treatment for recurrent disease.

Two instruments were used (read out under the comprehension of selected participates): 1) a semi-structured questionnaire to characterize the women according to their sociodemographic, clinical and health-related data;2) WHOQOL-bref to evaluate the quality of life of these women. WHOQOL-bref is a generic tool for evaluating quality of life that has been validated and culturally adapted for the Brazilian population. It is a short version of the World Health Organization (WHO) tool, WHOQOL-100. ${ }^{14}$ WHOQOL-bref is composed of 26 questions, among which two are about quality of life in general and the remaining 24 represent each of the facets of the original tool.

Questions are organized into four domains: physical (pain and discomfort; energy and fatigue; and sleep and rest) psychological (positive feelings; thinking, learning, memory and concentration; self-esteem; body image and appearance; and negative feelings); social (personal relations; social support and sexual activity); and environmental (physical safety and protection; home environment; financial resources; health and social care; availability and quality; opportunities to obtain new information and skills; participation and opportunities for recreation/leisure; physical environment, pollution, traffic noise/ climate; and transportation). The score for each question ranges from one to five points. 
The data were stored and analyzed using the Statistical Package for the Social Sciences (SPSS) software, version 15.0. In the descriptive analysis, the variables were represented by frequency distribution and by central trend and dispersion measurements. The Kolmogorov-Smirnov test was used to verify the normality of the variables and the Mann-Whitney test was used in bivariate analysis. Some variables were recoded into two categories to make bivariate analysis easier.

In the analysis on WHOQOL-bref, facet and domain scores were calculated on a scale from 0 to 100 , in which the closer to 100 that these scores were, the better the quality of life was. The scoring was done independently, considering the assumption that quality of life is a multidimensional construct. ${ }^{14,15}$ Pearson's correlation coefficient was used to ascertain the intensity of linear associations that existed among the scores of the WHOQOL dimensions (domains and questions on overall quality of life).

The research project was approved by the Ethics Committee. The interviews were started only after the participants had given their agreement through signing a free and informed consent statement and held in reserved offices with average medium time of forty minutes.

\section{RESULTS}

Regarding the sociodemographic characterization, the women affected by cervical cancer were aged between 26 and 69 years (mean $=45.72$ years; SD $=12.49$ years). They had predominantly attended school for eight years or more $(\mathrm{n}$ $=27 ; 58.70 \%)$, were mostly of mixed race $(n=30 ; 65.22 \%)$, were mostly unemployed $(n=20 ; 43.48 \%)$ and mostly had a partner $(n=27 ; 58.70 \%)$. Most of them had an income of up to one minimum monthly wage $(n=37 ; 80.43 \%)$ and lived in municipalities in the interior of the state of Pernambuco $(n=25$; $54.35 \%$ ) (Table 1).

In relation to clinical variables, the main histological type was squamous cell carcinoma $(n=42 ; 91.30 \%)$, and the disease was diagnosed when already at an advanced stage in 29 cases $(63.00 \%)$. The most common initial treatment was radiotherapy associated with chemotherapy $(n=28 ; 60.88 \%)$. The time taken to conclude the treatment ranged from 3 to 20 months (median = 5 months; $\mathrm{Q} 1=3 ; \mathrm{Q} 3=9$ ) (Table 1).

Regarding the characteristics relating to lifestyle habits, 36 $(78.26 \%)$ did not consume alcoholic beverages, $29(63.04 \%)$ did not smoke and $24(52.17 \%)$ had some sort of comorbidity. The main leisure activities performed by this group of women were recreational activities (36.96\%) (watching television/videos, listening to music or using the computer) and social activities (69.57\%) (meeting/getting together with friends, artistic group activities, voluntary work, family reunions, dancing/parties and trips and travel).

In the analysis on the women's quality of life after treatment, among the domains of WHOQOL-bref, those with the best averages were the social domain $(63.52 \pm 16.69)$ and the psychological domain $(61.48 \pm 14.87)$; the physical and environment domains presented the lowest scores (56.75 \pm
Table 1. Sociodemographic and clinical characteristics of the women who underwent cervical cancer treatment

\begin{tabular}{|c|c|c|}
\hline Sociodemographic variables & n (46) & $\%$ \\
\hline \multicolumn{3}{|l|}{ Years of schooling } \\
\hline Less than 8 years of schooling & 19 & 41.30 \\
\hline 8 years of schooling or more & 27 & 58.70 \\
\hline \multicolumn{3}{|l|}{ Race/color } \\
\hline Mixed & 30 & 65.22 \\
\hline White & 11 & 23.91 \\
\hline Black & 4 & 8.70 \\
\hline Yellow & 1 & 2.17 \\
\hline \multicolumn{3}{|l|}{ Marital status } \\
\hline with partner & 27 & 58.70 \\
\hline without partner & 19 & 41.30 \\
\hline \multicolumn{3}{|l|}{ Work situation } \\
\hline Unemployed & 20 & 43.48 \\
\hline Working in the home & 11 & 23.91 \\
\hline Employed & 7 & 15.22 \\
\hline On medical leave & 5 & 10.87 \\
\hline Other & 3 & 6.52 \\
\hline \multicolumn{3}{|l|}{ Location of the home } \\
\hline Recife and its metropolitan region & 21 & 45.65 \\
\hline Interior of the state of Pernambuco & 25 & 54.35 \\
\hline \multicolumn{3}{|l|}{ Monthly family income } \\
\hline Up to 1 minimum wage & 37 & 80.43 \\
\hline Over 1 minimum wage & 9 & 19.57 \\
\hline Clinical variables & n (46) & $\%$ \\
\hline \multicolumn{3}{|l|}{ Histological type of tumor } \\
\hline Squamous cell carcinoma & 42 & 91.30 \\
\hline Adenocarcinoma & 3 & 6.53 \\
\hline Other & 1 & 2.17 \\
\hline \multicolumn{3}{|l|}{ Stage } \\
\hline Advanced disease & 29 & 63.0 \\
\hline Early disease & 17 & 37.0 \\
\hline \multicolumn{3}{|l|}{ Treatment performed } \\
\hline Non-surgical (CT/RT) & 28 & 60.88 \\
\hline Surgical + Adjuvant (CT/RT) & 9 & 19.56 \\
\hline Surgical & 9 & 19.56 \\
\hline
\end{tabular}

21.32 and $53.06 \pm 12.75$, respectively), as shown in Table 2. The physical and psychological domains had the highest correlation between each other $(r=0.57)$, and also the greatest association with overall quality of life $(r=0.54$ and $r=0.63$, respectively) (Table 3). 
Table 2. Scores obtained for overall quality of life and in the WHOQOL-bref domains among the women after treatment for cervical cancer

\begin{tabular}{lccccc}
\hline Domains & Mean $(\mathbf{9 5 \%} \mathbf{C l})$ & SD & Median & Minimum & Maximum \\
\hline Physical & $56.75(50.34-63.15)$ & 21.32 & 60.71 & 14.29 & 100.00 \\
\hline Psychological & $61.48(57.01-65.95)$ & 14.87 & 62.50 & 20.83 & 83.33 \\
\hline Social & $63.52(58.50-68.53)$ & 16.69 & 58.33 & 8.33 & 91.67 \\
\hline Environmental & $53.06(49.22-56.89)$ & 12.75 & 56.25 & 25.00 & 81.25 \\
\hline Overall quality of life & $59.72(54.48-64.97)$ & 17.45 & 62.50 & 25.00 & 100.00 \\
\hline
\end{tabular}

Table 3. Correlation among the domains of WHOQOL-bref and between these and the overall quality of life of the women after treatment for cervical cancer

\begin{tabular}{lcccc}
\hline \multirow{2}{*}{ Domains and overall quality of life } & \multicolumn{4}{c}{ Domains } \\
\cline { 2 - 5 } & Physical & Psychological & Social & Environmental \\
\hline Physical & - & - & - & - \\
Psychological & $0.57^{*}$ & - & - & - \\
Social & $0.30^{\dagger}$ & $0.52^{*}$ & - & - \\
Environmental & 0.25 & $0.34^{\dagger}$ & 0.04 & - \\
Overall quality of life & $0.54^{*}$ & $0.63^{*}$ & $0.32^{\dagger}$ & $0.47^{*}$ \\
\hline
\end{tabular}

$* p<0.01 ;+p<0.05$.

In correlating the domains of the WHOQOL-bref with sociodemographic variables there were statistically significant differences (Table 4). Family income was associated with the "physical" domain $(p=0.04)$; and marital status was associated with the "overall quality of life" domain $(p=0.05)$. There was also a significant correlation between the WHOQOL-bref domains with lifestyle habits and with the clinical variables (Table 5). Recreational leisure activity was associated with the "social" domain $(p=0.01)$; and the type of treatment performed and comorbidities were associated with the "environment" domain ( $p=0.01$ and $p=0.02$, respectively).

\section{DISCUSSION}

The sociodemographic characteristics of the women treated for cervical cancer at were similar to what had previously been found in other studies in relation to age, race/color, marital status and schooling. ${ }^{16,17}$ It has more frequently been found that women affected by cervical cancer have lower schooling levels. ${ }^{16,17}$ Lower schooling level, which is considered to be a proxy for social stratification, has been correlated with non-healthy lifestyle habits ${ }^{18}$ and risky sexual behavior, ${ }^{19}$ which are determinants for occurrences of cervical cancer.

The average age of 45 years corroborates the current recommendations for performing preventive examinations on women between 25 and 64 years of age (target population). ${ }^{20}$ Mixed-race women with low income and low schooling level who are unemployed are more vulnerable to diseases such as cervical cancer, given that economic and social conditions decisively influence health conditions. ${ }^{21}$ Cervical cancer is associated with precarious living conditions ${ }^{22}$ and inefficient prevention programs. Screening using Papanicolaou is not very effective for reaching women in situations of social exclusion or for raising their awareness). ${ }^{23}$

The findings from the present study that carcinoma was the main histological type and that the disease was diagnosed at advanced stages are in accordance with the results from other studies. ${ }^{16,17}$ Women in situations of poverty have less access to healthcare services and, thus, receive later diagnoses. Moreover, there are obstacles preventing them from receiving specialized treatment in good time. ${ }^{24}$ The main treatment performed (chemotherapy and radiotherapy) is a consequence of late diagnosis. For diseases at advanced stages, the main therapeutic strategy consists of using radiotherapy in association with chemotherapy, in order to attain better therapeutic results. ${ }^{5}$

Over half of the women diagnosed were living in municipalities in the interior of the state of Pernambuco. This can be explained by the lower reach of prevention actions in municipalities in the interior and/or by the difficulty in accessing diagnosis and treatment facilities among the population living outside of major urban centers. ${ }^{25}$ However, it has been shown that in Brazil the decline in mortality due to cervical cancer has been greater among women living in state capital cities than among those living elsewhere in the respective states. This strengthens the hypothesis of inequality of access to services. ${ }^{25}$

Regarding lifestyle habits, a good proportion of the women stated that they did not consume alcoholic beverages and did not smoke. Among their leisure activities, recreational and social activities were the ones most often performed. Lifestyle is known to have a significant influence on quality of life among women 


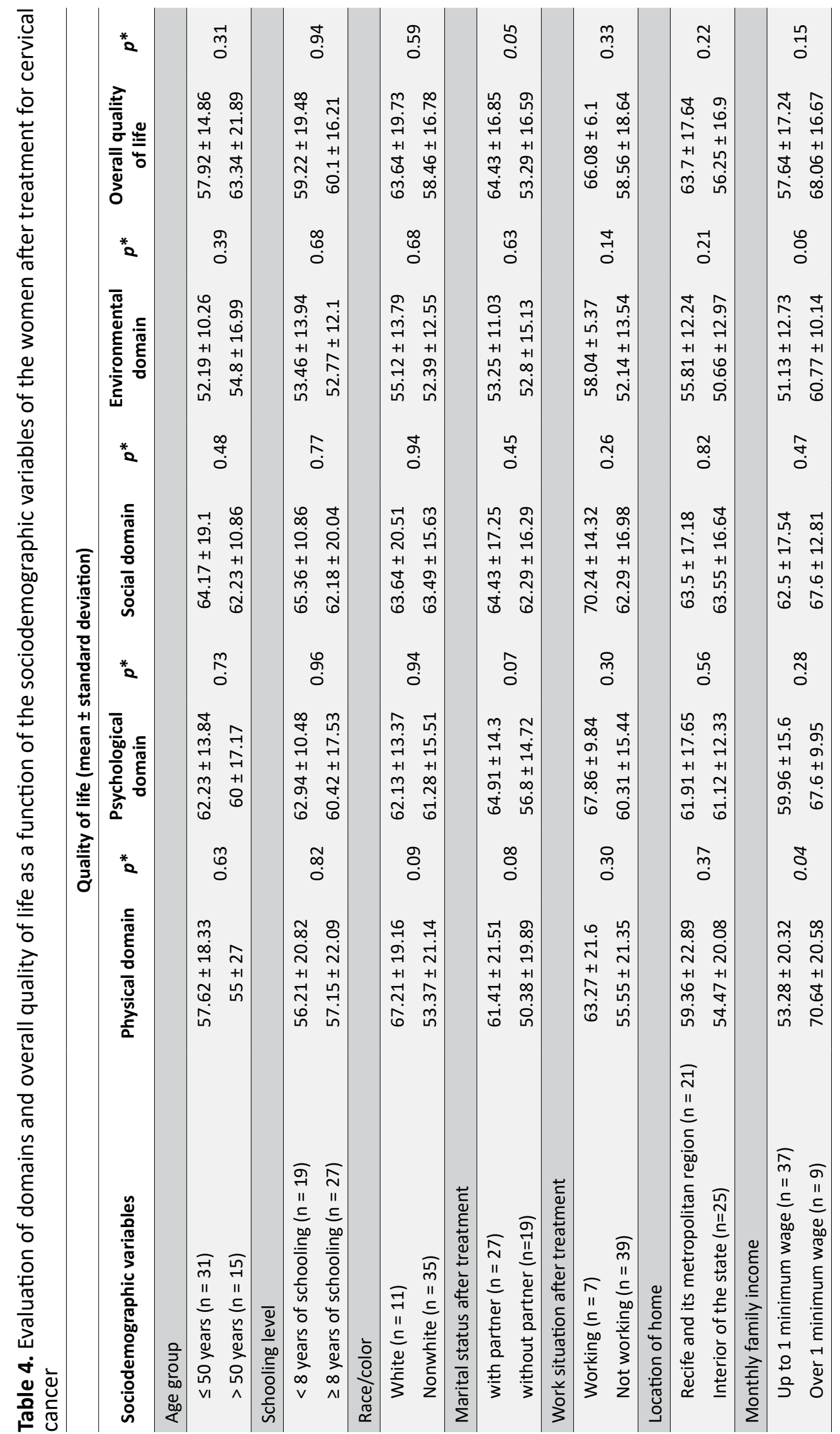




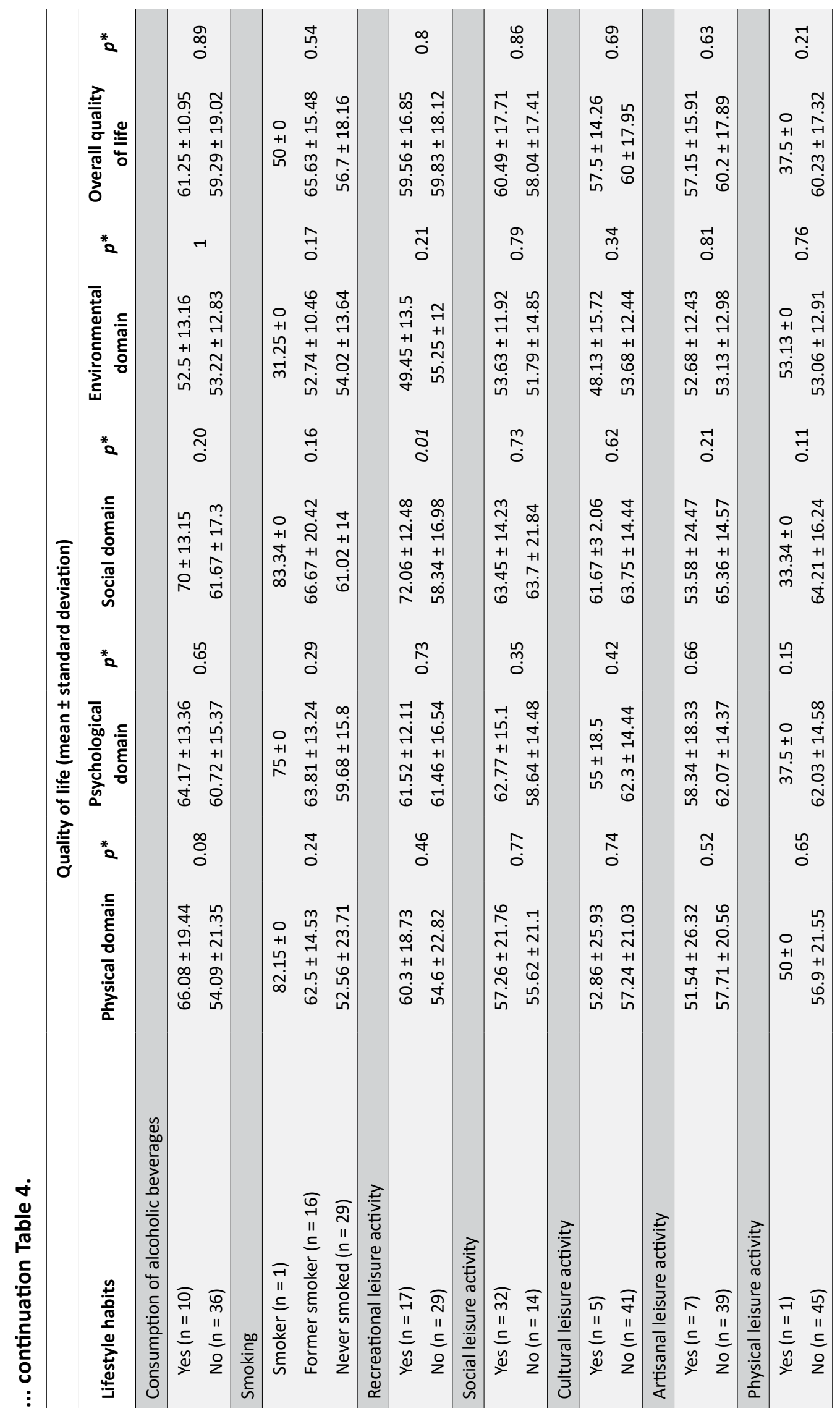




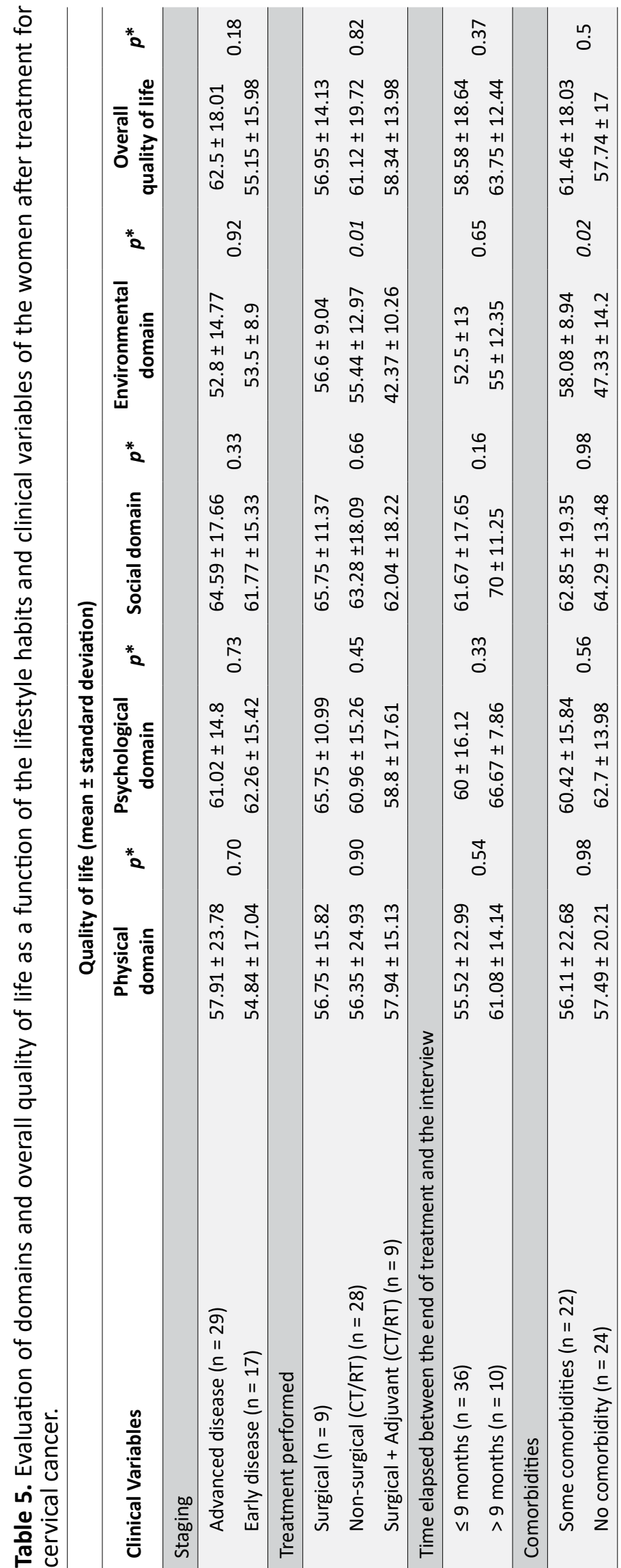


treated for cervical cancer, ${ }^{26}$ and leisure activities promote improvements in quality of life, since they provide maintenance of health and wellbeing. ${ }^{27}$

The quality of life of the women treated for cervical cancer in the present study was most influenced by the "physical" and "psychological" domains. Similar results were found by other authors in studying the quality of life of patients treated using chemotherapy. ${ }^{28}$ Indeed, the greater the physical and psychosocial damage caused by the disease and treatment is, the worse the quality of life will be. ${ }^{8}$

The physical domain, which was one of the domains with lowest average total score, is represented in WHOQOL-bref by facets referring to pain, discomfort, energy and fatigue, sleep and rest, dependence on medication and dependence on treatment, among others. Lower scores in these facets show the physical impact caused by treatment, which may even continue for several years after the treatment has finished. ${ }^{29}$ In turn, the lower scores in the "environment" domain can be explained by the fact that the sample predominantly comprised women living in conditions of poverty. In such situations, the lack of financial resources can make health, living and leisure conditions precarious. Economic difficulties are known to be related to lower scores for quality of life. ${ }^{30}$

The associations shown by socioeconomic variables (income, leisure activity and marital status), health-related variables (comorbidities) and clinical variables (type of treatment performed) in relation to the domains of WHOQOL-bref reaffirm the extent to which the quality of life of women after treatment is linked to socioeconomic and clinical situations. . $6,30,31^{20}$

The following factors showed a negative relationship with quality of life among the women treated for cervical cancer: marital status (social support is a protective and recuperative factor for health, since it assists in coping with the diseases and in treating it ${ }^{32}$ worse socioeconomic conditions; ${ }^{30}$ lack of opportunity for leisure (leisure enables tension relief, thereby promoting beneficial effects for quality of life; ${ }^{33}$ associations between cancer and other chronic pre-existing conditions; and undergoing types of therapy that include radiotherapy (worse physical, functional and social outcomes have been correlated with radiotherapy. ${ }^{31}$

\section{CONCLUSIONS}

The quality of life of the women studied here was associated with their clinical, socioeconomic and health-related conditions. Furthermore, their quality of life was associated with the type of treatment that they underwent (late diagnosis was reflected in treatment using radiotherapy and chemotherapy). Thus, it is imperative to be aware of the importance of early diagnosis through effective screening, especially among women in less favorable economic situations. Moreover, it is important to include measurements of quality of life in clinical practice, since these may be crucial in evaluating certain therapeutic interventions and the consequences of the disease on the lives of these women. Through measurement of quality of life, it may be possible to provide alternative measures that mitigate the secondary effects of treatment.

\section{REFERENCES}

1. World Health Organization (WHO). International Agency For Research On Cancer. Cervical cancer. Estimated incidence, mortality and prevalence worldwide in 2012. [Internet] 2012. [cited 2017 Dec 4]. Available from: http://globocan.iarc.fr/Pages/fact_sheets_cancer.aspx

2. Ministério da Saúde (BR). Instituto Nacional do Câncer José Alencar Gomes da Silva (INCA). Coordenação de Prevenção e Vigilância/ Divisão de Vigilância. Estimativa de Câncer no Brasil. [Internet] 2018. [cited 2018 Jul 7]. Available from: http://www.inca.gov.br/ estimativa/2018/casos-brasil-consolidado.asp

3. Stanley MA. Epithelial cell responses to infection with human papillomavirus. Clin Microbiol Rev [Internet]. 2012 Apr; [cited 2017 Dec 8]; 25(2):215-22. Available from: https://www.ncbi.nlm.nih.gov/ pmc/articles/PMC3346303/

4. Santos Filho MV, Gurgel AP, Lobo CD, Freitas AC, Silva-Neto JC, Silva LA. Prevalence of human papillomavirus (HPV), distribution of HPV types, and factors for infection in HPV-positive women. Genet Mol Res [Internet]. 2016 Jul; [cited 2018 Jul 9]; 15(2). Available from: https://www.ncbi.nlm.nih.gov/pubmed/?term=Prevalence+of+hum an+papillomavirus+(HPV)\%2C+distribution+of+HPV+types $\% 2 \mathrm{C}+$ and+factors+for+infection+in+HPV-positive+women.+Genet+Mol+Res.+2016+jul\%3B15(2)\%3A1-9

5. Touboul C, Skalli D, Guillo E, Martin M, Mallaurie E, Mansouri D, et al. Treatment of cervical cancer. Rev Prat [Internet]. 2014 Jun; [cited 2018 Jul 10]; 64(6):802-6. Available from: https://www.ncbi.nlm.nih. gov/pubmed/25090765

6. Ros C, Espuña M. Impact of cervical cancer treatment on micturition and sexual function. Actas Urol Esp [Internet]. 2013 Jan; [cited 2018 Jul 10]; 37(1):40-6. Available from: https://www.ncbi.nlm.nih.gov/pub $\mathrm{med} /$ ?term $=6 . \% 09 \mathrm{Ros}+\mathrm{C} \% 2 \mathrm{C}+$ Espu\%C3\%B1a+M.+Impact+of+cer vical+cancer+treatment+on+micturition+and+sexual+function.+Acta s+Urol+Esp

7. Corrêa CSL, Leite ICG, Andrade APS, Ferreira ASS, Carvalho SM, Guerra MR. Sexual function of women surviving cervical cancer. Arch Gynecol Obstet [Internet]. 2016 May; [cited 2018 Jul 10]; 293(5):105363. Available from: https://doi.org/10.1007/s00404-015-3857-0

8. Ye S, Yang J, Cao D, Lang J, Shen K. A Systematic Review of Quality of Life and Sexual Function of Patients with Cervical Cancer after Treatment. Int J Gynecol Cancer [Internet]. 2014 Sep; [cited 2017 Dec 26]; 24(7):1146-57. Available from: https://insights.ovid.com/ pubmed?pmid=25033255

9. Organização Pan-Americana de Saúde (OPAS). Organização Mundial de Saúde (OMS). Prevenção e controle de amplo alcance do câncer de colo do útero: um futuro mais saudável para meninas e mulheres [Internet]. [cited 2017 Dec 26]. Washington: Organização PanAmericana de Saúde; 2013. Available from: http://iris.paho.org/xmlui/ handle/123456789/3587

10. Garcia SN, Jacowski M, Castro GC, Galdino C, Guimarães PRB, Kaline LP. Os domínios afetados na qualidade de vida de mulheres com neoplasia mamária. Rev Gaúcha Enferm [Internet]. 2015 Apr/Jun; [cited 2018 Jul 8]; 36(2):89-96. Available from: http://dx.doi.org/10.1590/19831447.2015.02.45718

11. World Health Organization (WHO). Field Trial WHOQOL-100. Geneva: World Health Organization; 1995. [cited 2017 Dec 26]. Available from http://www.who.int/mental_health/who_qol_field_trial_1995.pdf

12. Fleck MPA. A avaliação de qualidade de vida: guia para profissionais da saúde. Porto Alegre: Artmed; 2008. [cited 2017 Dec 26]. Available from: http://www.scielo.br/pdf/rprs/v30n1/v30n1a19 
13. Ministério da Saúde (BR). Secretaria de Atenção à Saúde. Portaria № 140, de fevereiro de 2014. Redefine os critérios e parâmetros para organização, planejamento, monitoramento, controle e avaliação dos estabelecimentos de saúde habilitados na atenção especializada em oncologia e define as condições estruturais, de funcionamento e de recursos humanos para a habilitação destes estabelecimentos no âmbito do Sistema Único de Saúde (SUS). Brasília (DF): Ministério da Saúde; 2014. [cited 2017 Dec 26]. Available from: http://bvsms.saude. gov.br/bvs/saudelegis/sas/2014/prt0140_27_02_2014.html

14. Fleck MPA, Louzada S, Xavier M, Chachamovich E, Vieira G, Santos $\mathrm{L}$, et al. Application of the portuguese version of the instrument for the assessment of the quality of life of the World Health Organization (WHOQOL-100). Rev Saúde Pública [Internet]. 1999 Apr; [cited 2018 Jan 6]; 33(2):198-205. Available from: http://www.scielo.br/scielo. php?script=sci_arttext\&pid=S0034-89101999000200012

15. World Health Organization (WHO). WHOQOL-BREF: introduction, administration, scoring and generic version of the assessment. Field Trial Version [Internet]. Geneva: World Health Organization; 1996. [cited 2018 Jan 6] Available from: http://www.who.int/mental_health/media/en/76.pdf

16. Renna Junior NL, Silva GA. Temporal trend and associated factors to advanced stage at diagnosis of cervical cancer: analysis of data from hospital based cancer registries in Brazil, 2000-2012. Epidemiol Serv Saúde [Internet]. 2018 May; [cited 2018 Jul 8]; 27(2):e2017285. Available from: http://www.scielo.br/scielo.php?pid=S223796222018000200302\&script=sci_arttext\&tlng=en

17. Ribeiro JF, Silva ARV, Campelo V, Santos SLD, Coêlho DMM. Sociodemographic and clinical profile of women with cancer of the cervix in a city of North. Rev Eletrônica Gestão Saúde [Internet]. 2015; [cited 2018 Jan 12]; 5(4):2406-20. Available from: http://periodicos.unb. br/index.php/rgs/article/viewFile/13799/9733

18. Iser BPM, Yokota RTC, Sá NNB, Moura L, Malta DC. Protection from chronic diseases and the prevalence of risk factors in Brazilian state capitals - main results from Vigitel 2010. Ciênc Saúde Coletiva [Internet]. 2012 Sep; [cited 2018 Jan 12]; 17(9):2343-56. Available from: http://www.scielo.br/scielo.php?script=sci_arttext\&pid $=$ S1413-81232012000900015

19. Cruzeiro ALS, Souza LDM, Silva RA, Pinheiro RT, Rocha CLA, Horta BL. Sexual risk behavior: factors associated to the number of sexual partners and condom use in adolescents. Ciênc Saúde Coletiva [Internet]. 2010 Jun; [cited 2018 Jan 13]; 15(Suppl. 1):1149-58. Available from: http://www.scielo.br/scielo.php?script=sci_arttext\&pid=S1413$81232010000700023 \&$ lng =en\&nrm=iso\&tlng=en

20. World Health Organization (WHO). Cervical cancer screening in developing countries: report of a WHO consulation [Internet]. Geneva: World Health Organization; 2002. [cited 2018 Jan 13]. Available from: http://www.who.int/cancer/media/en/cancer_cervical_37321.pdf

21. Carvalho Al. Determinantes sociais, econômicos e ambientais da saúde. In: Fundação Oswaldo Cruz. A saúde no Brasil em 2030 - prospecção estratégica do sistema de saúde brasileiro: população e perfil sanitário [online]. Rio de Janeiro: Fiocruz/Ipea/Ministério da Saúde/Secretaria de Assuntos estratégicos da presidência da República; 2013. p. 19-38. [cited 2018 Jan 15]. Available from: http://books.scielo.org/id/8pmmy/ pdf/noronha-9788581100166-03.pdf

22. Tadesse SK. Socio-economic and cultural vulnerabilities to cervical cancer and challenges faced by patients attending care at Tikur Anbessa Hospital: a cross sectional and qualitative study. BMC Women Health [Internet]. 2015; [cited 2018 Jan 21]; 15:75. Available from: http://doi. org/10.1186/s12905-015-0231-0
23. Fonseca AJ, Ferreira LP, Dalla-Benetta AC, Roldan CN, Ferreira MLS. Epidemiology and economic impact of cervical cancer in Roraima, a Northern state of Brazil: the public health system perspective. Rev Bras Ginecol Obstet [Internet]. 2010; [cited 2018 Jan 15]; 32(8):386-92. Available from: http://www.scielo.br/pdf/rbgo/v32n8/a05v32n8.pdf

24. Madeiro A, Rufino AC, Brandão NS, Santos IS. Cervical cancer mortality trends in Piauí, 2000-2011. Cad Saúde Colet [Internet]. 2016 Jul/Sep; [cited 2018 Jan 18]; 24(3):282-5. Available from: http://www.scielo.br/ scielo.php?script=sci_arttext\&pid=S1414-462X2016000300282

25. Silva GA, Gamarra CJ, Girianelli VR, Valente JG. Cancer mortality trends in Brazilian state capitals and other municipalities between 1980 and 2006. Rev Saúde Pública [Internet]. 2011 Oct; [cited 2018 Jan 18]; 45(6):1009-18. Available from: http://www.scielo.br/scielo. php?pid=S0034-89102011000600002\&script=sci_arttext\&tlng=en

26. Iyer NS, Osann K, Hsieh S, Tucker JA, Monk BJ, Nelson EL, et al. Health Behaviors in Cervical Cancer Survivors and Associations with Quality of Life. Clin Ther [Internet]. 2016 Mar; [cited 2018 Feb 1]; 38(3):467-75. Available from: https://linkinghub.elsevier.com/retrieve/pii/S01492918(16)30058-3

27. Rocha FN, Bartholo MEC, Lima BD, Santos DO, Souza NE, Silva BGS Leisure and quality of life as perceived by people over 60 years. Rev Mosaico [Internet]. 2016 Jun/Dec; [cited 2018 Feb 1]; 7(2):4-9. Available from: http://editorauss.uss.br/index.php/RM/article/download/303/pdf

28. Mansano-Schlosser TC, Ceolim MF. Quality of life of cancer patients during the chemotherapy period. Texto Contexto Enferm [Internet]. 2012 Jul/Sep; [cited 2018 Feb 5];21(3):600-7. Available from: http://www.scielo. br/scielo.php?script=sci_arttext\&pid=S0104-07072012000300015

29. Soares MLCA, Trezza MCSF, Oliveira SMB, Melo GC, Lima KRS Leite JL. The healing cost: comfort and discomfort experiences of women undergoing brachytherapy. Esc Anna Nery [Internet]. 2016 Apr/Jun;20(2):317-23. Available from: http://www.scielo.br/scielo. php?pid=S1414-81452016000200317\&script=sci_arttext\&tlng=en

30. ACTION Study Group. Health-related quality of life and psychological distress among cancer survivors in Southeast Asia: results from a longitudinal study in eight low- and middle-income countries. BMC Med [Internet]. 2017 Jan; [cited 2018 Feb 6]; 15(1):10. Available from: https://www.ncbi.nlm.nih.gov/pubmed/?term=Health-related+quality+ of+life+and+psychological+distress+among+cancer+survivors+in+S outheast+Asia\%3A+results+from+a+longitudinal+study+in+eight+lowtand+middle-income+countries

31. Derks M, Van Lonkhuijzen LR, Bakker RM, Stiggelbout AM, Kroon CD, Westerveld $\mathrm{H}$, et al. Long-term morbidity and quality of life in cervical cancer survivors: a multicenter comparison between surgery and radiotherapy as primary treatment. Int J Gynecol Cancer [Internet]. 2017 Feb; [cited 2018 Feb 6];27(2):350-6. Available from: https://insights.ovid. $\mathrm{com} /$ pubmed?pmid $=27984376$

32. Moraes LP, Echevarría-Guanilo ME, Martins CL, Logaray TM Nascimento L, Braz DL, et al. Apoio social e qualidade de vida na perspectiva de pessoas que sofreram queimaduras. Rev Bras Queimaduras [Internet]. 2016; [cited 2018 Jul 07]; 15(3):142-7. Available from: http://www.rbqueimaduras.com.br/summary/35

33. Romão RLS. A importância do Lazer na promoção do Envelhecimento Bem-Sucedido [dissertação]. Portugal: Universidade do Algarve;2013. Available from: https://sapientia.ualg.pt/bitstream/10400.1/6670/1/ Tese\%20Raquel\%20Rom\%C3\%A3o.pdf 